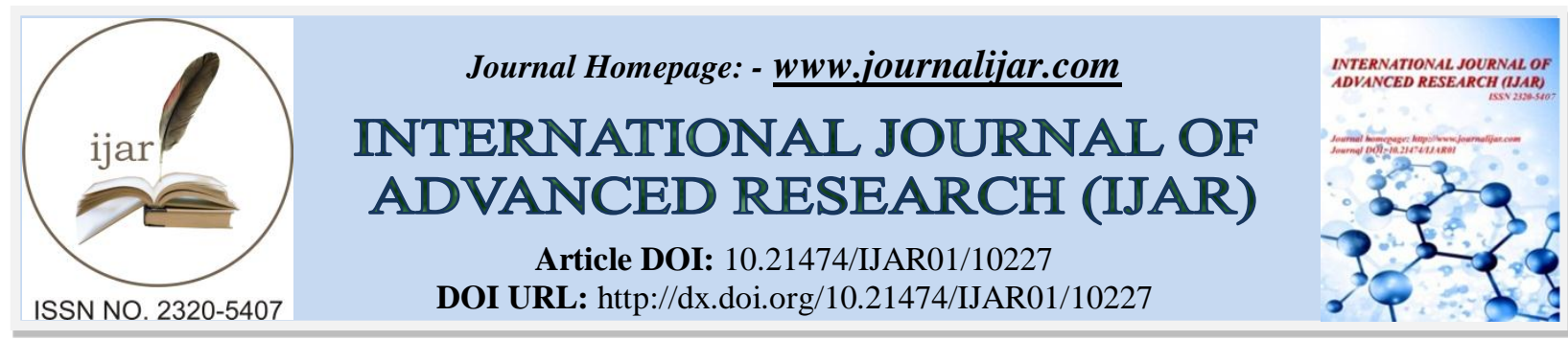

RESEARCH ARTICLE

\title{
STANDARDIZATION OF REGENERATION PROTOCOL FOR BANANA (MUSA SPP.) CV. GRAND NAINE AND ASSESSMENT OF SILICON EFFECT ON IN - VITRO GROWTH AND DEVELOPMENT
}

\author{
Magar Nakul ${ }^{1}$, Priya Shah ${ }^{1}$, Kharade Sachin ${ }^{1}$, Sonawane Chetan ${ }^{2}$ and N. S. Chavan ${ }^{1}$
}

1. Department of Plant Biotechnology, K. K. Wagh College of Agricultural Biotechnology, Nashik.

2. Lokmangal college of Agricultural Biotechnology, Wadala.

\section{Manuscript Info}

Manuscript History

Received: 10 October 2019

Final Accepted: 12 November 2019

Published: December 2019

Key words:-

Banana, In-Vitro Culture, BAP,

Regeneration, etc

\section{Abstract}

The present study was conducted to standardize the protocol for invitromicro propagation of banana(Musa spp.) cv. Grand Naine, shoot multiplication, root induction by using different concentrations of BAP, IAA, IBA and NAAand to evaluate the in-vitro effect of silicon on chlorophyll content of banana. The suckers were first surface sterilized with different sterilizing agent like $\mathrm{Hgcl}_{2}(0.1 \%)$ for $5 \mathrm{~min}$ and additionally sodium hypochlorite (5\%) for $10 \mathrm{~min}$ for avoiding contamination in establishment of culture. Among the different concentrations of hormones, the combination of BAP $3 \mathrm{mg} / \mathrm{l}+\mathrm{IAA} 2$ $\mathrm{mg} / \mathrm{l}$ gave the maximum results for the establishment of culture. For rooting, IAA $1 \mathrm{mg} / \mathrm{l}$ and NAA $1 \mathrm{mg} / \mathrm{l}$ gave the best results. These established cultures were further inoculated on MS media supplemented with various concentrations of Silicon component, Potassium silicate and Calcium silicate at $0.5,1,1.5 \mu \mathrm{g} / \mathrm{l}$ and these cultures were maintained for 30-35 days till the rooting stage. The media supplemented with Silicon led to increase in the chlorophyll content of the subcultured in-vitro propagated plantlets. Mainly the media supplemented with $0.5 \mathrm{mg} / \mathrm{l}$ of calcium silicate showed an enhanced effect on chlorophyll content.

Copy Right, IJAR, 2019,. All rights reserved.

\section{Introduction:-}

Edible banana (Musa spp.) is the major important staple food in the world which belongs to musa genus of the musaceae family. Cultivation of banana also contribute for the world's economic and social development as it is an important income source for rural population. Banana is a tropical fruit having the highest consumption (Donato et al.,2006). Many tropical and subtropical countries have banana as a major export commodity. Two diploid species of genus Musa, M. Acuminata (Malaysia) and M .Balbisiana (India) are the parent genome of cultivated banana (Simmonds 1962). The cultivation of banana through conventional methodsled to spread of various pest and diseases, andthis causes reduction in yield. Besides these, there are various other difficulties in classical breeding of banana due to its polyploidy and sterility in edible varieties (Stover and Simmonds, 1987).

Banana is a good source of carbohydrates, proteins, vitamins, minerals. In last several years, the productivity of land is lowered to the great extent and the continuously changing environment has stimulated a lot of challenges in the cultivation of banana. But the techniques in plant tissue culture such as micropropagation have been able to provide

Corresponding Author:- Magar Nakul

Address:- Department of Plant Biotechnology, K. K. Wagh College of Agricultural Biotechnology, Nashik. 
faster, healthier, shorter, stronger production and improve the yield as compare to the conventional method (Ortiz and vuylsteke, 1996). Micropropagation is use for the production of disease free millions of plants within a short period of time with high genetic and phytosanitary pattern. Alternative approach for banana improvement is the combination of mutation breeding and in-vitro culture (Novak et al.,1992).

The sexual crossing for breeding of new banana varieties is difficult because only a few pollens derived from diploid clones are viable which is then use in crosses with female fertile triploids for the production of new tetraploid seed (Shephered, 1987). Banana is traditionally propagated by suckers but it is laborious and time consuming while the tissue culture of banana have been reported to produce $39 \%$ higher yield than sword suckers. The primary explant source material like whole flower, buds, ovary sections and inflorescence have been used for in-vitro regeneration of banana.

Bacterial contamination has beenreported to be the major problem in the in-vitro propagation of banana. Initially surface sterilization workshowever in thelater bacterial contamination observed within 8-15 days of inoculation. Other problems in micropropagation is darkening of in-vitro cultured explant due to phenolic compound extruded from tissue on the media and its oxidation results into the formation of highly reactive and toxic substance, Quinone. This imparts the necessity to make use of antioxidant for the successful in-vitro culture.

The effective changes in the in-vitro environment were observed to occur particularly with the use of silicon ( $\mathrm{Si}$ ) in the acclimatization process ofthe cultured plants. Acclimatization in the in-vitro culture is an important stage, requires special attention forobtaining healthy and uniform culture. Silicon ( $\mathrm{Si}$ ) according to scientific communities has found to possess various effects such as it improves the leaf structure, enhance the photosynthetic activity (Asmar et al.,2013), induce metabolic reactions ultimately improves defense mechanisms, accumulation of phenolic compound and other chemicals such as phytoalexins and lignin (Pozzaet al.,2004), improve plant architecture thereby prevents the penetrations of pathogen and insect (Pozza and Pozza ,2003), accumulations of plant cell wall which physically results into reduction of water loss. Nevertheless, various studies have also reported that the invitro use of silicon provides improved chlorophyll content and cell wall component in plant. Hence, the development of a protocol for the micropropagation of banana is of prime importance.

\section{Material and Methods:-}

\section{Plant material and explant preparation:-}

Study was conducted in K.K.Wagh College of Agricultural Biotechnology, Nashik. The explant material, suckers were collected from Jalgaon district of Maharashtra state. The suckers of banana were excised from mother plant maintained insect and disease free condition at field and explants were cleaned under running tap water for about 10 to $15 \mathrm{~min}$. Suckers were surface sterilized with various combinations and concentrations of sterilizing agent like mercuric chloride $\left(\mathrm{Hgcl}_{2}\right)$, sodium hypochlorite, ethanol followed by thorough rinsing with sterile distilled water to avoid contamination.For the sterilization, initially the explants were disinfected with $0.5 \%$ Tween-20 liquid soap solution for 10-15 minutes to remove all the dust particles. Explants were soaked in fungicide (Bavistin) solution $(0.1 \%)$ for 20 minutes and then under laminar air flow the explants were three times washed with sterile distilled water. Streptomycin $(250 \mathrm{mg} / \mathrm{l})$ treatment was also given for 10 minutes and again two times washed with sterile distilled water. Finally, mercuric chloride $\left(\mathrm{Hgcl}_{2}\right)$ treatments $(0.5 \%)$ was given for 5-6 min followed by two to three times wash with sterile distilled water and additionally treatment with antioxidants, Ascorbic Acid (150 mg/l) and citric acid (100mg/l) was given and then wash 3 times with sterile distilled water.Now explants were further treated with $70 \%$ ethanol for $30 \mathrm{sec}$, and then followed by three times wash with sterile distilled water for complete sterilization of explants.

\section{Culture media and growth condition:-}

MS medium (Murashige and Skoog, 1962) with the addition of $30 \mathrm{gm} / 1$ sucrose and 8 gm/l agar. Media was supplemented with various concentrations of growth hormones BAP, IAA, NAA, to find the concentration of growth hormone for optimum growth of the in-vitro regenerated plants for culture establishment, shoot multiplication and root induction. The $\mathrm{pH}$ of media was maintained 5.6 to 5.8 before autoclaving for 15 minutes at $121^{\circ} \mathrm{c}$ and 15 p.s.i. Cultures were then incubated in a growth room at $25 \pm 2{ }^{\circ} \mathrm{C}$ with $16 / 8 \mathrm{~h}$ (light/dark) photoperiod at a photon flux of50-70 mmol m $\mathrm{m}^{-2}$ from cool white fluorescent tubes (Philips, India).After 50-60 days, the explantswith some shoots grown in-vitro were subcultured. 


\section{Root induction:-}

Multiplied shoots were further transferred to MS (Half) with eight different concentration of growth hormone Auxin like (IAA and NAA) to find out optimum concentration for rooting. After inoculation of in-vitro grown shoot, rooting was observed for about 15-25 days, after 45 days the cultured plantlets were prepared for hardening. The invitro generated plantlets were potted in mixture comprising of coco peat and garden soil $\mathrm{pH} 5.4$ in hardening glasses then the plantlets were transferred to greenhouse of college farm.

\section{Hardening of explants:-}

The rooted plantlets were thoroughly washed with tap water ensuring that all agar particles were completely removed without damaging the roots. Different media like, vermicompost, coco peat and soil were mixed in combination of 1:1:1 and filled in plastic pots. Further treatment of $0.05 \%$ bavistin was given to the rooted plantlets then finally planted in the plastic pots. A transparent plastic bag was used tocover the plantlets for six to seven days and temperature was maintained at $28^{\circ} \mathrm{C}$. The cover was gradually removed after seven days, initially for $3 \mathrm{~h}$ followed by $6 \mathrm{~h}$ and $12 \mathrm{~h}$ in next three days. The cover was removed during night and lights put-off for next three days. Subsequently, the period of keeping plantlets uncovered gradually increased and after 15 days the plantlets were kept in shade in outer environment. Within next 10 days by gradually exposing them to sun, they were acclimatized to natural environment andthe nutrient medium was gently removed and washed.

\section{Experimental design and statistical analysis:-}

The experiment was designed as per the RCBD (Randomized Complete Block Design) with three replications per treatment. Statistical analysis was carried out by performing ANOVA to determine the significant difference between the treatment means. Further by using the software SPSS ver.16.0 the comparison between the treatment mean was made using DMRT (Duncan's Multiple Range Test).

\section{Estimation of chlorophyll content:-}

Estimation of chlorophyll was carried out from banana (musa spp. cv.Grand naine) leaves, by $80 \%$ Acetone method by Porra, R. J. (2002)., collected from in vitro regenerated plant before treatment of silicon and after treatment of silicon by using $80 \%$ acetone method. The leaf sample weigh $150 \mathrm{mg}$ was taken and $80 \%$ acetone is added to it for crushing the sample using mortar and pestle. Then the grinded sample was centrifuged several times at 5000 r.p.m for $5 \mathrm{~min}$, until the green color of the sample was gone. The supernatant was collected in a volumetric flask $25 \mathrm{ml}$; the final volume is made $25 \mathrm{ml}$ by $80 \%$ acetone. The absorption of the extracts is measured with a spectrophotometer at the wavelengths 663,646 and $710 \mathrm{~nm}$. The wavelength of $710 \mathrm{~nm}$ is used to determine the absorption of possible compounds that may interfere with the measurements of the chlorophyll.For total chlorophyll content, the absorption at $652 \mathrm{~nm}$ is sufficient.

\section{Results:-}

\section{Culture establishment:-}

With different treatments, the days required for theculture establishment are given in the table 2. The observations show the establishment of culture on MS media with various concentration of growth hormones. The MS media is supplemented with BAP $(2.00,3.00,4.00,5.00 \mathrm{mg} / \mathrm{l})$ and combination of BAP $(2.00,3.00,4.00,5.00 \mathrm{mg} / \mathrm{l})$ with IAA $(1.00,2.00 \mathrm{mg} / \mathrm{l})$. It was observed that the minimum time was required by the media containing BAPin combination with IAA. The best results were obtained on media supplemented with BAP $3 \mathrm{mg} / \mathrm{l}$ and IAA $2 \mathrm{mg} / \mathrm{l}$ it require short time (16-18 days) for culture establishment.

Table no.1:- Effect of cytokinin and auxin on culture establishment of banana explant cv. Grand Naine.

\begin{tabular}{|c|c|c|}
\hline Treatment & $\begin{array}{l}\text { Time taken for establishment of } \\
\text { culture (days) } \pm \text { S.E }\end{array}$ & $\begin{array}{l}\text { Culture Establishment } \\
\text { frequency }(\%)\end{array}$ \\
\hline $\mathrm{MS}+\mathrm{BAP}(2.00 \mathrm{mg} / \mathrm{l})$ & $26.30 \pm 0.41$ & 56.76 \\
\hline $\mathrm{MS}+\mathrm{BAP}(3.00 \mathrm{mg} / \mathrm{l})$ & $24.00 \pm 0.32$ & 63.44 \\
\hline $\mathrm{MS}+\mathrm{BAP}(4.00 \mathrm{mg} / \mathrm{l})$ & $23.52 \pm 0.40$ & 69.21 \\
\hline $\mathrm{MS}+\mathrm{BAP}(5.00 \mathrm{mg} / \mathrm{l})$ & $24.12 \pm 0.33$ & 63.31 \\
\hline $\mathrm{MS}+\mathrm{BAP}(3.00 \mathrm{mg} / \mathrm{l})+\mathrm{IAA}(1.00 \mathrm{mg} / \mathrm{l})$ & $23.16 \pm 0.57$ & 71.82 \\
\hline $\mathrm{MS}+\mathrm{BAP}(4.00 \mathrm{mg} / \mathrm{l})+\mathrm{IAA}(1.00 \mathrm{mg} / \mathrm{l})$ & $21.30 \pm 0.46$ & 74.86 \\
\hline MS + BAP (3.00 mg/l) + IAA (2.00 mg/l) & $18.33 \pm 0.39$ & 83.59 \\
\hline $\mathrm{MS}+\mathrm{BAP}(4.00 \mathrm{mg} / \mathrm{l})+\mathrm{IAA}(2.00 \mathrm{mg} / \mathrm{l})$ & $21.64 \pm 0.56$ & 73.12 \\
\hline
\end{tabular}




\section{Culture proliferation:-}

Culture observed with the best shoot induction (BAP 3mg/l + IAA 2mg/l) were subcultured on media with different concentrations for culture proliferation. Table 3. Represents the number of shoots per explant for multiple shoot induction. The frequency of occurrence of multiple shoots was observed with different treatments of BAP (2.00, $3.00,4.00,5.00 \mathrm{mg} / \mathrm{l})$ in combination with IAA $(1.00,2.00 \mathrm{mg} / \mathrm{l})$. Among this the treatment of BAP $3 \mathrm{mg} / \mathrm{l}$ and IAA $2 \mathrm{mg} / \mathrm{l}$ gave the maximum shoot multiplication.

Table no. 2:- Effect of cytokinin and auxin on shoot proliferation of Banana explants cv.Grand naine.

\begin{tabular}{|c|c|c|c|}
\hline Treatment & \begin{tabular}{|lr} 
Culture & showing \\
Multiple & shoot \\
frequency $(\%)$
\end{tabular} & $\begin{array}{l}\text { Number of } \\
\text { shoots per } \\
\text { culture } \pm(\text { S.E) }\end{array}$ & $\begin{array}{lr}\text { Number } & \text { of } \\
\text { Leaves } & \text { on } \\
\text { shoot } \pm(\text { S.E }) & \end{array}$ \\
\hline $\mathrm{MS}+\mathrm{BAP}(2.00 \mathrm{mg} / \mathrm{l})$ & 33.16 & $2.3 \pm .30$ & $3.3 \pm 0.31$ \\
\hline $\mathrm{MS}+\mathrm{BAP}(3.00 \mathrm{mg} / \mathrm{l})$ & 52.26 & $3.0 \pm 0.05$ & $5.5 \pm 0.36$ \\
\hline $\mathrm{MS}+\mathrm{BAP}(4.00 \mathrm{mg} / \mathrm{l})$ & 59.33 & $4.6 \pm 0.32$ & $5.0 \pm 0.06$ \\
\hline $\mathrm{MS}+\mathrm{BAP}(5.00 \mathrm{mg} / \mathrm{l})$ & 47.15 & $3.0 \pm 0.51$ & $4.3 \pm 0.42$ \\
\hline $\mathrm{MS}+\mathrm{BAP}(3.00 \mathrm{mg} / \mathrm{l})+\mathrm{IAA}(1.00 \mathrm{mg} / \mathrm{l})$ & 61.29 & $4.4 \pm 0.33$ & $6.0 \pm 0.53$ \\
\hline $\mathrm{MS}+\mathrm{BAP}(4.00 \mathrm{mg} / \mathrm{l})+\mathrm{IAA}(1.00 \mathrm{mg} / \mathrm{l})$ & 66.09 & $4.3 \pm 0.40$ & $6.4 \pm 0.27$ \\
\hline MS + BAP (3.00 mg/l) + IAA (2.00 mg/l) & 76.34 & $6.6 \pm 0.31$ & $7.3 \pm 0.31$ \\
\hline $\mathrm{MS}+\mathrm{BAP}(4.00 \mathrm{mg} / \mathrm{l})+\mathrm{IAA}(2.00 \mathrm{mg} / \mathrm{l})$ & 69.55 & $5.2 \pm 0.29$ & $6.1 \pm 0.54$ \\
\hline $\begin{array}{l}\mathrm{MS}+\mathrm{BAP}(3.00 \mathrm{mg} / \mathrm{l})+\mathrm{NAA}(1.00 \mathrm{mg} / \mathrm{l})+\mathrm{IAA}(1.00 \\
\mathrm{mg} / \mathrm{l})\end{array}$ & 71.38 & $5.0 \pm 0.48$ & $6.2 \pm 0.38$ \\
\hline $\begin{array}{l}\mathrm{MS}+\mathrm{BAP}(4.00 \mathrm{mg} / \mathrm{l})+\mathrm{NAA}(1.00 \mathrm{mg} / \mathrm{l})+\mathrm{IAA}(1.00 \\
\mathrm{mg} / \mathrm{l})\end{array}$ & 55.84 & $4.6 \pm 0.32$ & $5.6 \pm 0.52$ \\
\hline
\end{tabular}

\section{In-vitro rooting:-}

From the data collected, the response of the culture explant for root induction to the auxin containing media is presented in the table 4 . The 12 different media supplemented with different concentrations of IAA and NAA or in combination with BAP were used. Out of these MS (half strength) + IAA $(1 \mathrm{mg} / \mathrm{l})$ showed maximum rooting invitro. While the combination of BAP $5 \mathrm{mg} / \mathrm{l}+\mathrm{IAA} 1 \mathrm{mg} / \mathrm{l}+\mathrm{NAA} 1 \mathrm{mg} / \mathrm{l}$ showed the superior result overall the different concentrations of plant growth hormones used for in-vitro rooting as it required very less time for rooting.

Table no. 3:- Effect of auxin on in-vitro rooting character of banana plantlets cv. Grand naine.

\begin{tabular}{|c|c|c|c|}
\hline Treatment & $\begin{array}{l}\text { Time taken } \\
(\text { Days }) \pm(\text { S.E })\end{array}$ & $\begin{array}{l}\text { Culture rooting } \\
\text { frequency }(\%)\end{array}$ & $\begin{array}{l}\text { Number of roots per } \\
\text { culture } \pm(\text { S.E })\end{array}$ \\
\hline MS (half strength) + IAA $(0.5 \mathrm{mg} / \mathrm{l})$ & $11.6 \pm 0.32$ & 61.89 & $4.3 \pm 0.0 .23$ \\
\hline MS (half strength) + IAA $(1.00 \mathrm{mg} / \mathrm{l})$ & $8.72 \pm 0.27$ & 82.63 & $6.4 \pm 0.46$ \\
\hline MS (half strength) + IAA $(1.5 \mathrm{mg} / \mathrm{l})$ & $10.5 \pm 0.56$ & 74.45 & $4.5 \pm 0.39$ \\
\hline MS (half strength) + IAA $(2.00 \mathrm{mg} / \mathrm{l})$ & $13.8 \pm 0.29$ & 62.18 & $3.2 \pm 0.41$ \\
\hline MS (half strength) + NAA $(0.5 \mathrm{mg} / \mathrm{l})$ & $10.0 \pm 0.54$ & 73.39 & $4.6 \pm 0.32$ \\
\hline MS (half strength) + NAA $(1.00 \mathrm{mg} / \mathrm{l})$ & $10.3 \pm 0.34$ & 68.19 & $4.3 \pm 0.22$ \\
\hline MS (half strength) + NAA $(1.5 \mathrm{mg} / \mathrm{l})$ & $16.6 \pm 0.61$ & 42.95 & $3.0 \pm 0.27$ \\
\hline MS (half strength) + NAA $(2.00 \mathrm{mg} / \mathrm{l})$ & $16.0 \pm 0.05$ & 40.52 & $2.4 \pm 0.44$ \\
\hline $\begin{array}{l}\text { MS (half strength) + NAA }(1.00 \mathrm{mg} / \mathrm{l})+\mathrm{IAA} \\
(1.00 \mathrm{mg} / \mathrm{l})\end{array}$ & $14.5 \pm 0.42$ & 74.00 & $4.4 \pm 0.36$ \\
\hline $\begin{array}{l}\text { MS (half strength) + NAA }(2.00 \mathrm{mg} / \mathrm{l})+\mathrm{IAA} \\
(2.00 \mathrm{mg} / \mathrm{l})\end{array}$ & $12.6 \pm 0.36$ & 46.48 & $3.0 \pm 0.21$ \\
\hline MS basal media (half strength) & $18.0 \pm 0.48$ & 32.67 & $1.3 \pm 0.33$ \\
\hline
\end{tabular}

\section{Chlorophyll content:-}

Culture observed with the best shoot induction (BAP $3 \mathrm{mg} / \mathrm{l}+\mathrm{IAA} 2 \mathrm{mg} / \mathrm{l}$ ) were subcultured on media with various concentrations of Silicon component, Potassium silicate and Calcium silicate at $0.5,1,1.5 \mu \mathrm{l} / \mathrm{l}$ and $\mu \mathrm{g} / \mathrm{l}$ respectively and these cultures were maintained for 30-35 days till rooting stage. The effect of silicon containing media is that it led to increase in the chlorophyll content of the subcultured in-vitro propagated plant. Mainly the media supplemented with $0.5 \mathrm{mg} / \mathrm{l}$ of calcium silicate show enhanced effect on chlorophyll content. 
Table no. 4:- In vitro Effect of Silicon on chlorophyll content of banana cv.Grand naine for standard result i.e (BAP $3 \mathrm{mg} / \mathrm{l}+\mathrm{IAA} 2 \mathrm{mg} / \mathrm{l})$.

\begin{tabular}{|l|l|l|l|l|l|}
\hline Concentration of media & Source of Silicon & $\begin{array}{l}\text { Chl.a } \\
(\mathbf{m g} / \mathbf{l}) \pm(\mathbf{S . E})\end{array}$ & $\begin{array}{l}\text { Chl.b } \\
(\mathbf{m g} / \mathbf{l}) \pm(\mathbf{S . E})\end{array}$ & $\begin{array}{l}\text { Total } \\
\text { Chl. } \\
(\mathbf{m g} / \mathbf{l})\end{array}$ & Mean \\
\hline $\begin{array}{l}\text { Control } \\
(\mathrm{BAP} 3 \mathrm{mg} / \mathrm{l}+\mathrm{IAA} 2 \mathrm{mg} / \mathrm{l})\end{array}$ & & $0.77 \pm 0.01$ & $0.98 \pm 0.03$ & 1.77 & 0.88 \\
\hline (BAP 3mg/l + IAA 2 mg/l) & $\mathrm{K}_{2} \mathrm{Sio}_{3}(50 \mu \mathrm{l} / \mathrm{l})$ & $1.34 \pm 0.09$ & $1.12 \pm 0.06$ & 2.36 & 1.18 \\
\hline (BAP 3mg/l + IAA 2 mg/l) & $\mathrm{K}_{2} \mathrm{Sio}_{3}(100 \mu \mathrm{l} / \mathrm{l})$ & $1.42 \pm 0.05$ & $1.14 \pm 0.01$ & 2.52 & 1.26 \\
\hline (BAP 3mg/l + IAA 2 mg/l) & $\mathrm{K}_{2} \mathrm{Sio}_{3}(150 \mu \mathrm{l} / \mathrm{l})$ & $1.03 \pm 0.09$ & $0.92 \pm 0.01$ & 1.94 & 0.97 \\
\hline (BAP 3mg/l + IAA 2 mg/l) & Casio $_{4}(50 \mu \mathrm{g} / \mathrm{l})$ & $1.12 \pm 0.02$ & $1.48 \pm 0.05$ & 2.52 & 1.26 \\
\hline (BAP 3mg/l + IAA 2 mg/l) & Casio $_{4}(\mathbf{1 0 0} \mu \mathbf{\mu g} / \mathbf{l})$ & $\mathbf{1 . 8 2} \pm \mathbf{0 . 0 2}$ & $\mathbf{1 . 7 4 \pm 0 . 0 3}$ & $\mathbf{3 . 6 2}$ & $\mathbf{1 . 8 1}$ \\
\hline (BAP 3mg/l + IAA 2 mg/l) & Casio $_{4}(150 \mu \mathrm{g} / \mathrm{l})$ & $1.34 \pm 0.06$ & $1.13 \pm 0.04$ & 2.45 & 1.22 \\
\hline
\end{tabular}

\section{Conclusion:-}

In conclusion, we have established a standard protocol with different media compositions of phytohormones for micropropagation of banana cv. Grand Naine. The results of this study indicates that the calcium silicate has an effective role on the enhancement of cholorophyll content of leaves. While, the BAP (3.00 mg/l) with IAA (2.00 $\mathrm{mg} / \mathrm{l}$ ) establishes the culture in short time duration with maximum proliferation. Rooting of plantlets was observed to be optimum on the MS (half strength) with IAA $(1.00 \mathrm{mg} / \mathrm{l})$. Therefore through the in-vitro micropropagation of banana with various media composition can be used on commercial scale for large scale propagation of healthy and disease free banana cv. Grand Naine.

\section{References:-}

1. Ahmed, S., Sharma, A., Singh, A. K., Wali, V. K., \& Kumari, P. (2014). In vitro multiplication of banana (Musa sp.) cv. Grand Naine. African Journal of Biotechnology, 13(27).

2. Asmar SA, Castro EM, Pasqual M, Pereira FJ, Soares JDR (2013) Changes in leaf anatomy and photosynthesis of micropropagated banana plantlets under different silicon sources. Sci Hortic. 161(1):328-332.

3. Asmar, S. A., Rodrigues Soares, J. D., Lara Silva, R. A., Pasqual, M., Pio, L. A. S., \& Mauro de Castro, E. (2015). Anatomical and structural changes in response to application of silicon ( $\mathrm{Si}$ )'in vitro'during the acclimatization of banana cv.'Grand Naine'. Australian Journal of Crop Science, 9(12), 1236.

4. Donato SLR, Silva SO, Lucca Filho OA, Lima MB, Domingues H, Alves JSC (2006) Comportamento de variedades e híbridos de bananeira (Musa spp.) em dois ciclos de produção no sudoeste da Bahia. Rev Bras Frut. 28(1):139-144

5. Murashige, T., \& Skoog, F. (1962). A revised medium for rapid growth and bio assays with tobacco tissue cultures. Physiologia plantarum, 15(3), 473-497.

6. Novak, F.J. 20 Musa (Bananas and Plantains). In: HAMMERSCHLAG, F.A.; LITZ, R.E. (Eds.). Biotechnology of perennial fruit crops. Wallingford, UK: CAB International, 1992. p.449-488.

7. Ortiz, R., \& Vuylsteke, D. (1996, October). Recent advances in Musa genetics, breeding and biotechnology. In Plant Breeding Abstracts (Vol. 66, No. 10).

8. Porra, R. J. (2002). The chequered history of the development and use of simultaneous equations for the accurate determination of chlorophylls a and $b$. Photosynthesis research, 73(1-3), 149-156.

9. Pozza EA, Pozza AAA (2003) Manejo de doença de plantas com macro e micronutrientes. Ver Bras Fitopat. 28(4):5254.

10. Pozza AAA, Alves E, Pozza EA, Carvalho JG, Montanari M, Guimarães PTG, Santos DM (2004) Efeito do silício no controle da cercosporiose em três variedades de cafeeiro. Fitopatol Bras. 29(2):185-18.

11. Sandoval JA, Müller LE, Weberling F (1994) Foliar morphology and anatomy of Musa cv. Grande Naine (AAA) plants grown in vitro and during hardening as compared to field-grown plants. Fruits. 49(1):37-46.

12. Shephered, K. Banana breeding: Past and present. Acta Horti. 196: 37-43 (1987).

13. Simmonds, N. W. 1962 The Evolution of the Bananas. 1962 pp.170 pp. ref.bibl. 7.

14. Stover, R. H., \& Simmonds, N. W. (1987). Bananas. Longman Scientific and Technical. Harlow, Essex, UK.

15. Yao X, Chu J, Cai K, Liu L, Shi J, Geng W (2011) Silicon improves the tolerance of wheat seedlings to ultraviolet-B stress. Biol Trace Elem Res. 143(1):507-517. 